\title{
KAJIAN KEUNTUNGAN ANTARA PENYERTAAN MODAL PADA USAHA PEMBENIHAN IKAN GURAMI (Oshpronemus gouramy, Lac) DENGAN PEROLEHAN BUNGA DEPOSITO BANK
}

\author{
Oleh \\ Iskandar Musa, Ganjar Wiryati \\ Dosen Jurusan Penyuluhan Perikanan Sekolah Tinggi Perikanan
}

\begin{abstract}
ABSTRAK
Ikan gurami (Oshpronemus gouramy, Lac) merupakan ikan asli Indonesia dan berasal dari perairan daerah Jawa Barat, Kegiatan pembenihan ikan gurami untuk ber produksi menggunakan sumber daya modal finansial. Sumber daya modal finansial merupakan faktor produksi yang harus dikelola secara efisien dan efektif. Usaha pembenihan ikan gurami umumnya dilaksanakan dalam skala usaha rumah tangga. Mendepositokan uang di bank termasuk usaha memperoleh pendapatan dari bunga yang diberikan sebagai imbal jasa atas penyertaan sejumlah uang pada sebuah lembaga keuangan atau bank. Penelitian dengan menggunakan metode Deskriftif kuantitatif melalui berbagai analisa yang di lakukan, hasil uji/penelitian didasarkan pada variable-variable input dan output sehingga dapat diperoleh suatu perbandingan antara penyertaan modal terhadap usaha pembenihan ikan gurami dengan menempatkan dana dalam bentuk deposito pada bank.

Penelitian di lakukan di wilayah kecamatan Kemang dengan Responden pembudidaya ikan gurame, Tujuan penelitian yaitu 1. membandingkan mana yang lebih menguntungkan antara penyertaan modal pada usaha pembenihan ikan gurami (Oshpronemus gouramy, Lac) atau perolehan bunga deposito bank 2. Memberikan gambaran bagi calon investor dalam pengambilan keputusan peggunaan dana antara investasi pada usaha pembenihan ikan gurami atau deposito.

Dari hasil kajian yang di lakukan maka dapat disimpulkan bahwa Usaha pembenihan ikan gurami dengan sekuen kegiatan selama 3 bulan secara finansial layak untuk dilaksanakan. Hal ini didukung oleh beberpa parameter kelayakan yang dipakai pada penelitian ini dengan hasil analisis : 1) Keuntungan per tahun (4 kali produksi) $=\operatorname{Rp} 33.153 .725,-\quad 2$ 2) $\mathrm{R} / \mathrm{C}=2,1$ 3) Payback Period 0,6 (Kurang dari 1 tahun) 4) BEP produksi $=\mathrm{Rp} 450,-=66.3$ ekor. $\quad$ BEP harga $=\mathrm{Rp}$ 213,2,-Jika total modal usaha pembenihan ini sebesar Rp 29.846.275,- didepositokan maka setiap bulan akan menghasilkan jasa atau keuntungan sebesar Rp 176.093,Sedangkan keuntungan yang diperoleh pada usaha pembenihan ikan gurami setiap 3 bulan mencapai $\operatorname{Rp} 33.153 .725$,- atau Rp 11.051.241,- per bulan. Dari data yang di tunjukan memiliki Arti bahwa keuntungan usaha pembenihan ikan gurami bisa mencapai $111,08 \%$ lebih besar dibanding deposito.
\end{abstract}

Kata Kunci: Modal, Finansial, deposito 
PENDAHULUAN

\section{Latar Belakang}

Ikan gurami (Oshpronemus gouramy, Lac) merupakan ikan asli Indonesia dan berasal dari perairan daerah Jawa Barat. Ikan ini merupakan salah satu komoditi perikanan air tawar yang cukup penting apabila dilihat dari permintaannya yang cukup besar dan harganya yang relatif tinggi dibandingkan dengan ikan air tawar lainnya seperti ikan mas, nila, tambakan dan tawes, dan merupakan salah satu sumber protein yang cukup tinggi. Bagi masyarakat umum, ikan ini dipandang sebagai salah satu ikan bergengsi dan biasanya disajikan pada acara-acara yang dianggap penting. Oleh sebab itu, tidak mengherankan apabila ikan gurami menjadi salah satu komoditi unggulan di sektor perikanan air tawar.

Usaha pembenihan dan pendederan ikan gurami di daerah Kemang telah berkembang sejak lama dan dilakukan oleh masyarakat setempat secara turun menurun sehingga umumnya sudah menguasai keterampilan dan pengetahuan. Alasan lain yang membuat masyarakat setempat membenihkan ikan gurami adalah karena mudah dan permintaannya cukup tinggi, serta penggunan lahan untuk kegiatannya tidak terlalu luas. Dari segi kondisi lingkungan, berkembangnya usaha pembenihan ikan gurami juga didukung oleh tersedianya kuantitas dan kualitas air yang cukup dan pemenuhan aspek-aspek teknis yang sesuai untuk pengembangan usaha pembenihan dan pendederan ikan gurami.

Pembinaan terhadap pembenihan ikan secara umum selama ini dilakukan oleh Dinas Perikanan dimana mempunyai Balai Benih Ikan (BBI) sebagai unit pelaksana teknis yang tersebar di beberapa tempat. Sebagian besar pembenih masih menggunakan teknologi semi intensif dan tradisional, dan hanya sebagian kecil saja yang menggunakan teknologi intensif. Penggunaan teknologi ini erat kaitannya dengan terbatasnya pengetahuan, informasi dan modal.

Usaha pembenihan ikan gurami umumnya dilaksanakan oleh masyarakat dalam skala usaha rumah tangga, artinya belum menerapkan konsep usaha secara ekonomis dengan menggunakan analisa usaha yang benar. Tujuan dari pada suatu usaha seperti halnya pembenihan ikan gurami merupakan salah satu kegiatan perekonomian masyarakat dalam rangka memperoleh pendapatan (income). Banyak kegiatan dan cara yang dapat dilakukan untuk memperoleh pendapatan ditinjau dari segi resiko. Ada kegiatan usaha yang memiliki resiko besar, sedang dan kecil, tergantung pada pola dan jenis usaha yang akan dijalankan. Usaha yang memiliki resiko tinggi biasanya menjanjikan output yang tinggi, demikian pula sebaliknya.

Mendepositokan uang di bank termasuk usaha memperoleh pendapatan dari bunga yang diberikan sebagai imbal jasa atas penyertaan sejumlah uang pada sebuah lembaga keuangan atau bank.Secara umum di Indonesia, deposito identik dengan simpanan deposito berjangka atau time deposit. Deposito adalah produk bank yang memberikan bunga lebih tinggi dari simpanan biasa, bila kita menyimpan uang tersebut dengan jangka waktu tertentu. Simpanan deposito hanya bisa ditarik setelah jangka waktu tertentu. 


\section{Rumusan Masalah}

Setiap kegiatan perekonomian tentu mengharapkan efesiensi dan efektifitas dalam penggunaan faktorfaktor produksi. Kegiatan pembenihan ikan gurami salah satu kegiatan produksi yang menggunakan sumber daya modal finansial. Sumber daya modal finansial merupakan faktor produksi yang harus dikelola secara efisien dan efektif dalam penggunaannya seperti faktor produksi lain yang berupa bahan atau barang, karena biaya akan terus dikeluarkan seiring dengan berjalannya waktu. Untuk itu penggunaanya harus tepat agar tidak terjadi pemborosan.

Dengan metode analisis data yang diambil dari data deskriftif hasil uji/penelitian yang didasarkan pada variable-variable input dan output maka dapat diperoleh suatu perbandingan antara penyertaan modal terhadap usaha pembenihan ikan gurami dengan menempatkan dana dalam bentuk deposito pada bank.

\section{Tujuan penelitian}

1. Membandingkan mana yang lebih menguntungkan antara penyertaan modal pada usaha pembenihan ikan gurami (Oshpronemus gouramy, Lac) atau perolehan bunga deposito bank

2. Memberikan gambaran bagi calon investor dalam pengambilan keputusan peggunaan dana antara investasi pada usaha pembenihan ikan gurami atau deposito.

\section{KERANGKA PIKIR, VARIABEL PENELITIAN DAN HIPOTESIS}

\section{Kerangka Pemikiran}

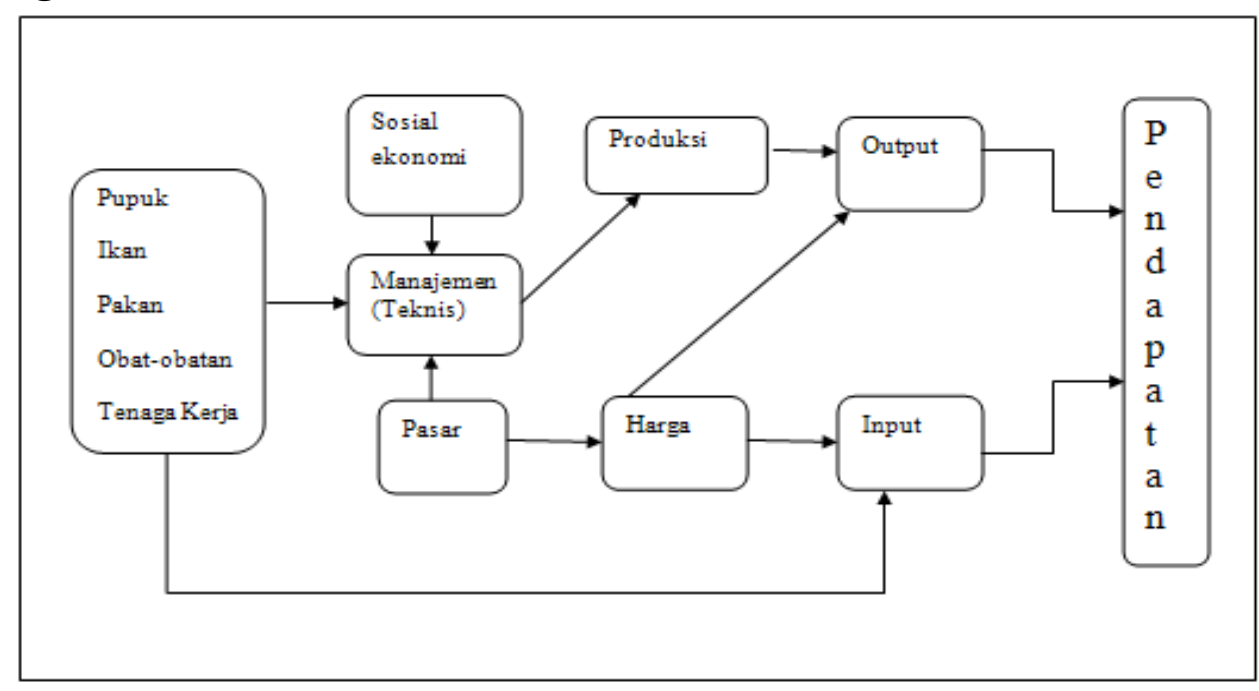

Gambar 1. Kerangka pemikiran

Gambar diatas dapat diuraikan mengenai penjelasannya sebagai berikut :

Faktor-faktor produksi diproses dengan melakukan menejemen dan penanganan teknis serta berinteraksi dan dipengaruhi oleh faktor sosial ekonomi dimana kegiatan dilakukan, yang nantinya akan menghasilkan produk sesuai dengan besaran input yang diberikan. Hasil nilai nominal dari produksi atau total output dipengaruhi 
oleh tingkat harga barang hasil produksi, harga sangat dipengaruhi kualitas barang, posisi tawar dan harga pasar. Harga pasar dipengaruhi oleh tingkat equilibirium antara suplai dan permintaan serta jenis barang substitusinya.

Faktor penentu dari hasil akhir atau output bersih yang kemudian dinyatakan dalam bentuk nominal berupa pendapatan adalah besaran total jumlah produksi dikalikan harga satuan dikurangi input total. Dimana secara rasional dan dalam keadaan normal besaran jumlah produksi berkorelasi dengan besaran jumlah input yang diberikan, dalam kegiatan usaha pembenuhan ikan gurami besaran jumlah input secara maksimal dibatasi oleh faktor teknis yaitu besarnya skala usaha (luas kolam, jumlah induk dan faktor-faktor produksi lainnya) .

\section{Variabel Penelitian}

a. Faktor internal perusahaan

1) Harga

2) Jumlah produksi

\section{Hipotesis}

Dengan menganalisis variablevariabel input dan output pada usaha pembenihan ikan gurami akan dapat memberikan informasi mana yang lebih menguntungkan antara pembenihan ikan gurami dengan perolehan bunga deposito bank pada penggunaan modal yang setara.

\section{METODE PENELITIAN}

\section{Metode Penelitian}

Deskriftif kuantitatif mengenai usaha perikanan dapat dilakukan. Tujuan analisis usaha adalah untuk mengetahui tingkat keuntungan, pengembalian investasi, maupun titik impas suatu usaha. Kajian tentang Keuntungan antara usaha pembenihan ikan gurami (Oshpronemous gouramy, Lac) dengan perolehan bunga deposito bank akan menggunakan pendekatan analisis usaha perikanan secara sederhana yang mudah diaplikasikan pada usaha perikanan skala kecil dan menengah.

\section{Analisis Laba/Rugi}

Analisis laba/rugi bertujuan untuk mengetahui besarnya keuntungan atau kerugian dari suatu usaha yang dikelola. Suatu usaha dikatakan untung bila nilai penerimaan (revenue) lebih besar dari total pengeluaran atau biaya (cost)

\section{Revenue Cost Ratio (R/C)}

Analisis R/C merupakan alat analisis untuk mengetahui keuntungan relatif suatu usaha dalam satu tahun terhadap biaya yang dipakai dalam kegiatan tersebut. Suatu usaha dikatakan layak bila $\mathrm{R} / \mathrm{C}$ lebih besar dari 1 $(\mathrm{R} / \mathrm{C}>1)$.

Semakin tinggi nilai $\mathrm{R} / \mathrm{C}$ maka tingkat keuntungan suatu usaha akan semakin tinggi. Sebaliknya bila $\mathrm{R} / \mathrm{C}$ lebih kecil dari $1(\mathrm{R} / \mathrm{C}<1)$, maka usaha itu dikatakan tidak layak, karena tidak menguntungkan.

$$
\mathrm{R} / \mathrm{C}=\text { Total Penerimaan }: \text { Total Biaya }
$$

\section{Payback Period (PP)}

Payback period adalah suatu cara analisis untuk mengetahui waktu tingkat pengembalian investasi yang telah ditanamkan pada suatu jenis usaha. Secara umum, rumus yang digunakan adalah :

$\mathrm{PP}=$ Total Investasi : Keuntungan $\mathrm{x} 1$ tahun 


\section{Break Even Point ( BEP )}

Analisis BEP merupakan alat analisis untuk mengetahui batas nilai produksi atau volume produksi suatu usaha mencapai titik impas (tidak untung dan tidak rugi). Usaha dinyatakan layak bila nilai BEP produksi lebih besar dari jumlah unit yang sedang diproduksi saat ini. Untuk menghitung BEP dapat menggunakan rumus sebagai berikut :
BEP $($ unit $)=$
$\mathrm{FC}: \mathrm{P}-\mathrm{VC}$
BEP $($ rupiah $)=$
$\mathrm{FC}: 1-\mathrm{VC} / \mathrm{P}$

Atau

BEP produksi $=$ Total biaya $:$ Harga penjualan BEP harga $=$ Total biaya : Total produksi

Dimana: $\mathrm{FC}=$ Fixed Cost $($ Biaya tetap RataRata Biaya Investasi Usaha Pembenihan Ikan Gurami)

$\mathrm{VC}=$ Variable Cost (Biaya tidak tetap)

$\mathrm{P}=$ Price $($ Harga $)$

\section{Tempat dan Waktu Penelitian}

Penelitian dilakukan di unit usaha pembenihan rakyat (UPR) yang berlokasi di Kecamatan Kemang,
Kabupaten Bogor. Kegiatan ini dilakukan dari bulan Juni sampai dengan bulan Agustus 2014.

\section{HASIL DAN PEMBAHASAN}

\section{Analisa Usaha}

Analisis usaha pembenihan dilakukan pada unit usaha yang dipilih berdasarkan kriteria usah yang mendekati standar usaha pembenihan ikan gurami sesuai dengan standar yang direkomendasi oleh Kementrian Kelautan dan Perikanan (KKP) dengan data produksi sebagai berikut.

1) Induk yang digunakan sebanyak 22 ekor, terdiri atas 5 ekor jantan dan 17 ekor betina.

2) Berat rata-rata induk $2-2,5 \mathrm{~kg} /$ ekor.

3) Lama produksi hingga siap jual adalah 3 bulan.

4) Jumlah benih yang dihasilkan sekali produksi sebanyak 34.650 ekor.

5) Sintasan atau kelangsungan hidup $60 \%$

6) Tenaga kerja 1 orang.

Tabel 1. Rata-Rata Biaya Operasional Usaha Pembenihan Ikan Gurami

\begin{tabular}{|l|l|l|}
\hline \multicolumn{1}{|c|}{ Komponen Biaya Tetap } & \multicolumn{1}{|c|}{ ( Produksi (Rp)/3bulan } & \multicolumn{1}{c|}{ Tahun (Rp) } \\
\hline Listrik & 225.000 & 900.000 \\
\hline Administrasi & 50.000 & 200.000 \\
\hline Komunikasi & 150.000 & 600.000 \\
\hline Sewa kolam & 300.000 & 1.200 .000 \\
\hline Gaji karyawan & 3.000 .000 & 12.000 .000 \\
\hline Tunjangan & 800.000 & 3.200 .000 \\
\hline Pajak Bumi \& Bangunan & 9.000 & 36.000 \\
\hline Transportasi & 150.000 & 600.000 \\
\hline Penyusutan & - & $\mathbf{3 . 3 3 3 . 6 7 5}$ \\
\hline Jumlah Biaya Tetap & - & $\mathbf{2 2 . 0 6 9 . 6 7 5}$ \\
\hline Komponen Biaya Variabel & $\mathbf{1} \times$ Produksi (Rp)/3bln & $\mathbf{1 ~ T a h u n ~ ( R p ) ~}$ \\
\hline Pakan induk & 1.200 .000 & 4.800 .000 \\
\hline Pakan larva & 548.250 & 2.193 .000 \\
\hline Pupuk, kapur & 23.900 & 95.600 \\
\hline Ijuk/sarang & 24.500 & 98.000 \\
\hline Obat-obatan & 25.000 & 100.000 \\
\hline Oksigen & 75.000 & 300.000 \\
\hline Plastik packing & 20.000 & 80.000 \\
\hline Karet gelang & 2.500 & 10.000 \\
\hline Kardus & 25.000 & 100.000 \\
\hline Jumlah Biaya Variabel & & $\mathbf{7 . 7 7 6 . 6 0 0}$ \\
\hline Total Biaya Operasional & & $\mathbf{2 9 . 8 4 6 . 2 7 5}$ \\
\hline & & \\
\hline
\end{tabular}


Tabel 2. Rata-Rata Perhitungan Penerimaan Pembenihan Ikan Gurami

\begin{tabular}{|c|c|c|}
\hline \multicolumn{1}{|c|}{ Penerimaan } & $\mathbf{1} \times$ Produksi/3 bln & $\mathbf{1}$ Tahun \\
\hline Produksi (ekor) & 35.000 & 140.000 \\
\hline Harga jual (Rp/ekor) & 450 & 450 \\
\hline Jumlah (Rp) & $\mathbf{1 5 . 7 5 0 . 0 0 0}$ & $\mathbf{6 3 . 0 0 0 . 0 0 0}$ \\
\hline
\end{tabular}

\section{Analisa Kelayakan}

\section{Laba/Rugi}

Keuntungan per tahun 4 kali produksi $=$ Penerimaan - (Total biaya)

Rp 63.000.000,- - Rp 29.846.275,- = Rp 33.153.725,-

Revenue Cost Ratio (R/C)

$\mathrm{R} / \mathrm{C}=$ Total Penerimaan : Total Biaya

Rp 63.000.000,- : $\operatorname{Rp~29.846.275,-=}$ 2,1

Payback Period (PP)

$\mathrm{PP}=$ Total Investasi : Keuntungan $\mathrm{x} 1$ tahun

Rp 20.303.500,- : Rp 33.153.725,- $\times 1$ tahun $=0,6$ ( Kurang dari 1 tahun)

\section{Break Even Point ( BEP)}

BEP produksi $=$ Total biaya : Harga penjualan :

Rp 29.846.275,- : $\quad$ Rp 450,- $=66,3$ ekor

BEP harga $=$ Total biaya $:$ Total produksi :

Rp 29.846.275,- : 140.000,- = Rp 213,2

Pada analisis laba/rugi diperoleh laba atau keuntungan sebesar $\mathrm{Rp}$ 33.153.725,- per tahun atau Rp 24.038.431,- per periode (3 bulan). Untuk $\mathrm{R} / \mathrm{C}$ ratio 2,1,- lebih besar dari 1 , artinya usaha ini layak dijalankan, karena setiap pengeluaran $\mathrm{Rp} \mathrm{1,-} \mathrm{bisa}$ menghasilkan Rp. 1,1,- Dalam hal investasi, usaha pembenihan ikan gurami dengan nilai investasi sebesar Rp 20.303.500,- bisa kembali dalam waktu kurang dari 1 tahun, dengan kata lain uang sebesar itu akan kembali setelah 1 kali produksi. Sedangkan Break Even Point (BEP) atau titik impas, usaha ini akan mengalami tidak untung dan tidak rugi, bila produksi sebanyak 66.3 ekor. Atau bila harga jualnya Rp 213,2 per ekor.

Usaha pembenihan ikan gurami dalam kajian yang dilakukan di daerah Ciseeng memerlukan modal sebesar Rp 50.149 .775 ,- yang terdiri atas modal investasi sebesar $\quad \mathrm{Rp} 20.303 .500$,dan modal operasional Rp 29.846.275,-

Ditinjau dari aspek kelayakan finansial, usaha pembenihan ikan gurami mulai dari pemijahan sampai umur 3 bulan menghasilkan benih dapat dikategorikan layak. Usaha ini juga lebih menguntungkan ditinjau dari segi penyertaan modal dibandingkan dengan bunga deposito.

Rata-rata perolehan bunga deposito berjangka pada bank pemerintah dan swasta saat ini (23 Agustus 2014) sebesar 7,09\% per tahun atau $0,59 \%$ per bulan. Jika total modal usaha pembenihan ini sebesar Rp 50.149.775,- didepositokan maka setiap bulan akan menghasilkan jasa atau keuntungan sebesar Rp 295.883,Sedangkan keuntungan yang diperoleh pada usaha pembenihan ikan gurami setiap 3 bulan mencapai Rp 32.051.241,- atau Rp 889.303 per bulan. Artinya keuntungan usaha 
pembenihan ikan gurami bisa mencapai $\mathbf{2 5 , 4} \%$ lebih besar dibanding deposito.

\section{KESIMPULAN DAN SARAN}

\section{Kesimpulan}

Berdasarkan hasil dan pembahasan penelitian dengan judul ; Kajian Keuntungan Antara Usaha Pembenihan Ikan Gurami (Oshpronemous gouramy, Lac) Dengan Perolehan Bunga Deposito Bank, dapat disimpulkan sebagai berikut:

1. Usaha pembenihan ikan gurami dengan sekuen kegiatan selama 3 bulan secara finansial layak untuk dilaksanakan. Hal ini didukung oleh beberpa parameter kelayakan yang dipakai pada penelitian ini dengan hasil analisis : 1) Keuntungan per tahun (4 kali produksi) = Penerimaan - (Total biaya) Rp 63.000.000,- - Rp 19.846.275,- = $\mathrm{Rp} 33.153 .725,-\quad$ 2) $\mathrm{R} / \mathrm{C}=$ Total Penerimaan : Total Biaya $\mathrm{Rp}$ 63.000.000,- : $\operatorname{Rp} 29.846 .275,-=$ $2,13) \quad P P=$ Total Investasi : Keuntungan $\mathrm{x} 1$ tahun $\mathrm{Rp}$ 20.303.500,- : Rp 33.153.725,- x 1 tahun $=0,6$ (Kurang dari 1 tahun) 4) $\mathrm{BEP}$ produksi $=$ Total biaya : Harga penjualan : R p 29.846.275,- : Rp 450,- $=66.3$ ekor. BEP harga $=$ Total biaya : Total produksi : Rp 29.846.275,- : 140.000 $=\operatorname{Rp} 213,2,-$

2. Jika total modal usaha pembenihan ini sebesar Rp 50.149.775,didepositokan maka setiap bulan akan menghasilkan jasa atau keuntungan sebesar Rp 295.883,-
Sedangkan keuntungan yang diperoleh pada usaha pembenihan ikan gurami setiap 3 bulan mencapai Rp 8.288.431,- atau Rp 2.762.810,per bulan. Artinya keuntungan usaha pembenihan ikan gurami bisa mencapai $933 \%$ lebih besar dibanding deposito.

\section{Saran}

Kajian tentang mana yang lebih menguntungkan antara penyertaan modal pada usaha pembenihan ikan gurami (Oshpronemus gouramy, Lac) atau perolehan bunga deposito bank perlu mempertimbangkan faktor resiko dimana dalam kajian ini hal tersebut belum dilakukan.

\section{DAFTAR PUSTAKA}

Effendi, Irzal dan Oktariza W. 2006 Manajemen Agribisnis Perikanan. Penebar Swadaya, Jakarta

Hanafiah dan Saefudin. 2006. Tataniaga Hasil Perikanan. Universitas Indonesia. Jakarta

Nasrudin. W dan Nuraini Ida. 2006. Manajemen Agribisnis. Universitas Terbuka.

Rahadi, F., Nazaruddin, dan Regina Kristiawati. 2005. Agribisnis $P$

Simorangkir, O. P, Drs , Dasar-dasar dan Mekanisme Perbankan, Aksara Persada Indonesia, Jakarta, 1986.

Suyatmo, Thomas, Drs, dkk,. 1988. Kelembagaan Perbankan, Gramedia Jakarta.

Undang-Undang RI No. 10 tahun 1998, Tentang Perbankan, Sekretariat Kabinet RI, Jakarta, 